\title{
PENENTUAN DERAJAT LUKA DALAM VISUM ET REPERTUM PADA KASUS LUKA BAKAR
}

\author{
${ }^{1}$ Erwin G. Kristanto \\ ${ }^{2}$ Sonny J. R. Kalangi \\ ${ }^{1}$ Bagian Kedokteran Forensik \& Medikolegal Fakultas Kedokteran \\ Universitas Sam Ratulangi Manado \\ ${ }^{2}$ Bagian Anatomi-Histologi Fakultas Kedokteran Universitas Sam Ratulangi Manado \\ Email: gk_erwin@yahoo.com
}

\begin{abstract}
Kebutuhan masyarakat atas berbagai dokumen medikolegal kian meningkat seiring peningkatan kesadaran masyarakat atas hak hukumnya. Setiap dokter, dalam berbagai tingkat pelayanan kesehatan, diwajibkan mampu untuk memberikan pelayanan forensik dan medikolegal, khususnya visum et repertum. Visum et repertum yang dibuat seorang dokter harus dapat membantu penegakan hukum melalui kesimpulan yang sesuai dengan ilmu kedokteran dan kebutuhan penegakan hukum.

Pada kasus dugaan penganiayaan yang mengakibatkan korban menderita luka bakar, maka amat penting bagi para penegak hukum untuk memperoleh pendapat ilmiah dokter mengenai derajat keparahan atau derajat luka dari korban tersebut. Pendapat ilmiah mengenai derajat luka ini akan membantu aparat penegak hukum dalam menentukan beratnya hukuman yang diancamkan pada pelaku. Kesimpulan dokter akan membawa dampak besar bagi pihak-pihak yang terlibat dalam tindak pidana tersebut, sehingga pengambilan kesimpulan yang tepat amatlah penting.
\end{abstract}

\section{LUKA BAKAR}

Luka bakar merupakan salah satu jenis luka, dimana terjadi kerusakan jaringan/ diskontinuitas jaringan yang diakibatkan sumber panas ataupun suhu dingin yang tinggi, sumber listrik, bahan kimiawi, cahaya, radiasi dan friksi. Jenis luka dapat beraneka ragam dan memiliki penanganan yang berbeda tergantung jenis jaringan yang terkena luka bakar, tingkat keparahan, dan komplikasi yang terjadi akibat luka tersebut. Luka bakar dapat merusak jaringan otot, tulang, pembuluh darah, jaringan epidermal dan jaringan lainnya. Korban luka bakar dapat mengalami komplikasi lokal berupa pembentukan parut dan kontraktur, maupun komplikasi sistemik. Faktor kontribusi utama dari komplikasi sistemik ini adalah rusaknya integritas kulit dan kehilangan cairan.
Penentuan derajat luka untuk kepentingan visum et repertum pada kasus luka bakar dilakukan dengan menilai: kedalaman luka bakar, luas luka bakar, hasil pemeriksaan penunjang, dan trauma yang menyertai luka bakar. Hasil penilaian tiap faktor di atas kemudian dikaji untuk dibandingkan dengan delik yang ada pada Kitab Undang-Undang Hukum Pidana (KUHP).

\section{KEDALAMAN LUKA}

Kedalaman luka menjadi salah satu tolok ukur utama dalam menentukan derajat luka pada kasus luka bakar. Klasifikasi kedalaman luka pada kulit yang diterima secara umum di dunia kedokteran saat ini adalah pembagian seperti yang tercantum dalam Tabel 1. 
Tabel 1. Tabel klasifikasi kedalaman luka bakar

\begin{tabular}{ccl}
\hline Klasifikasi & Kedalaman & \multicolumn{1}{c}{ Contoh Temuan Klinis } \\
\hline Superficial thickness & Epidermis & \multicolumn{1}{c}{ Eritema, udema } \\
\hline Partial thickness & Sampai sebagian & Timbul vesikel dan bula \\
& dermis & Rusaknya folikel rambut \\
\hline Full thickness & Seluruh dermis dan & Daerah terbakar tampak kering \\
& jaringan lemak di & dengan penurunan sensasi \\
& bawahnya & Folikel rambut dengan mudah \\
& dicabut \\
\hline
\end{tabular}

Kerusakan jaringan di bawah kulit akibat luka bakar, untuk kepentingan penilaian derajat luka dianggap sejajar dengan luka bakar full thickness.

\section{LUAS LUKA BAKAR}

Luas luka bakar adalah faktor penentu berikutnya dalam menentukan derajat luka pada kasus luka bakar. Perkiraan luas luka bakar yang umum digunakan dalam pengelolaan kasus forensik klinik adalah dengan menggunakan metode "Rule of Nine" dari Wallace dan Lund-Browder.

Pada anak-anak, perkiraan luas luka bakar pada kepala dan tungkai (huruf a,b dan c pada Gambar 1) disesuaikan dengan tabel dari Lund-Browder sebagai faktor koreksi (Tabel 2).

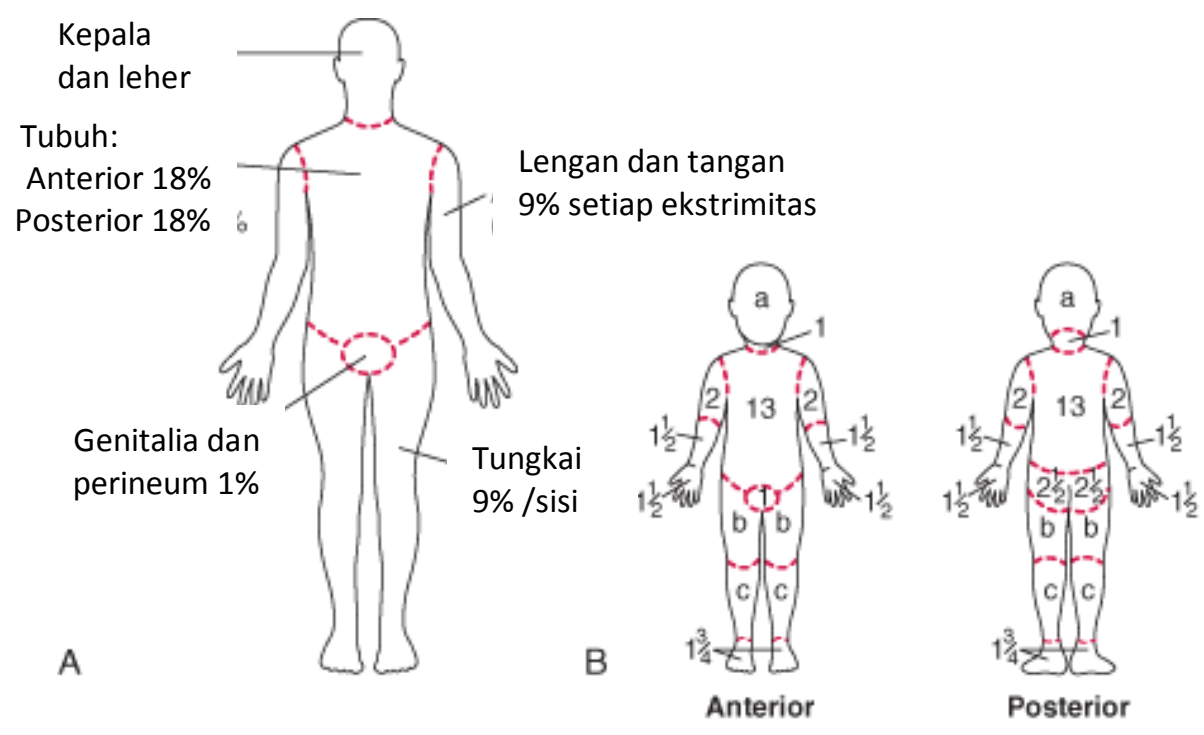

Gambar 1. Perkiraan luas luka bakar dari Wallace, Sumber: Artz CP, Moncrief JA, 1969.

Tabel 2. Tabel Lund-Browder

\begin{tabular}{|c|c|c|c|c|c|}
\hline \multirow{2}{*}{ Bagian tubuh } & \multicolumn{5}{|c|}{ Umur (dalam tahun) } \\
\hline & $\mathbf{0}$ & 1 & 5 & 10 & 15 \\
\hline $\mathrm{a}=1 / 2$ kepala & $9 \frac{1}{1 / 2}$ & $8 \frac{1}{2}$ & $61 / 2$ & $51 / 2$ & $41 / 2$ \\
\hline $\mathrm{b}=1 / 2$ dari 1 paha & $23 / 4$ & $31 / 4$ & 4 & $4 \frac{1}{4}$ & $4 \frac{1}{2}$ \\
\hline$c=1 / 2$ dari 1 tungkai bawah & $2 \frac{1 / 2}{2}$ & $2 \frac{1}{2}$ & $23 / 4$ & 3 & $31 / 4$ \\
\hline
\end{tabular}




\section{PEMERIKSAAN PENUNJANG}

Evaluasi kedokteran forensik dalam kepentingan menentukan derajat luka untuk pembuatan visum repertum, pada beberapa kasus akan membutuhkan pemeriksaan penunjang berupa: pemeriksaan darah, pemeriksaa urin, dan foto toraks.

Pemeriksaan darah dilakukan untuk mendeteksi terjadinya hipoalbuminemia. Hipoalbuminemia sebagian terjadi akibat hemodilusi, terutama pada korban yang memperoleh resusitasi cairan, dan sebagian lagi akibat hilangnya protein karena rusaknya kapiler. Pada korban juga dapat terjadi hipomagnesia, hipofosfatemia dan hipokalemia akibat pemberian cairan.

Pemeriksaan urin untuk mendeteksi terjadinya hemoglobinuria. Luka bakar dapat menyebabkan rabdomiolisis, yang akan menyebabkan mioglobinuria atau hemolisis yang merusak ginjal. Pada ginjal dapat terjadi nekrosis tubular akut dan kegagalan ginjal, sehingga pada kasus tertentu, pemeriksaan fungsi ginjal perlu dilakukan.

Foto toraks dapat membantu mendeteksi adanya kerusakan akibat inhalasi udara panas, asam, atau inhalan lain yang merusak saluran nafas korban.

\section{TRAUMA YANG MENYERTAI LUKA BAKAR}

Luka bakar pada seorang korban dapat terjadi bersamaan dengan cedera lain, dan sering disebut dengan combined burn trauma (CBT). Sekitar 1-5\% kasus dengan luka bakar, pada saat yang sama juga menderita luka akibat trauma tumpul atau tajam. Dua puluh lima hingga tiga puluh persen korban bencana massal atau serangan teroris akan menderita luka bakar, selain luka jenis lain yang mereka derita. CBT umumnya terjadi pada kecelakaan sepeda motor yang diiringi ledakan, kebakaran dengan runtuhnya gedung, luka bakar listrik, dan jatuhnya pesawat udara. Adanya trauma penyerta ini akan memperparah kondisi korban.

Luka bakar dan inhalasi udara panas sering terjadi bersamaan. Saat udara panas terhirup, umumnya faring dan saluran nafas atas turut mengalami luka bakar. Kondisi yang lebih parah dapat terjadi bila yang terhirup adalah uap panas, karena uap dapat menyimpan energi panas lebih banyak dan karena dapat membakar hingga saluran nafas bawah. Sebagian kematian pada kasus luka bakar, terjadi segera setelah terjadi spasme laring akibat udara panas yang terhirup.

\section{PENENTUAN DERAJAT LUKA}

Luka bakar dengan ciri-ciri luka bakar superfisial thickness dengan luas total kurang dari $10 \%$ total luas permukaan tubuh pada korban dengan usia di atas dua tahun dan di bawah enam puluh tahun, secara umum dapat digolongkan dalam derajat luka ringan.

Luka bakar full thickness lebih dari 1\% dari total luas permukaan tubuh, atau lebih dari 5\% dari total luas permukaan tubuh pada partial-thickness, harus digolongkan dalam luka derajat sedang. Luka bakar partial thickness atau lebih dalam, bila mengenai tangan, wajah, kaki atau perineum, tanpa melihat luas total permukaan tubuh yang terkena, juga masuk dalam penggolongan luka derajat sedang. Luka bakar yang masuk derajat ini, memerlukan evaluasi seksama di rumah sakit.

Kasus luka bakar harus dipertimbangkan masuk dalam derajat luka berat bila luas daerah luka bakar $>40 \%$ dari total permukaan tubuh atau adanya jenis trauma lain yang simultan terjadi pada tubuh korban (CBT), termasuk adanya inhalasi udara panas atau iritan yang merusak saluran nafas.

Kondisi lain yang memenuhi persyaratan pasal 90 Kitab Undang-Undang Hukum Pidana seperti timbulnya syok hipovolemik, yang bila ditemukan juga harus menjadi pertimbangan dokter untuk menggolongkan luka dalam derajat luka berat.

Penentuan derajat luka dilakukan setelah pengobatan dan perawatan selesai dilakukan, atau apabila dokter menetapkan bahwa perjalanan penyakit korban, tidak 
lagi dapat merubah kondisi derajat luka korban. Timbulnya komplikasi lokal yang dapat menyebabkan disabilitas pada korban seperti timbulnya eschar dan sindrom kompartemen, tidak boleh luput dari penilaian dokter dalam pembuatan visum et repertum.

\section{DAFTAR PUSTAKA}

1. Konsil Kedokteran Indonesia. Standar Kompetensi Dokter Indonesia. Jakarta: Konsil Kedokteran Indonesia, 2012.

2. Kitab Undang-undang Hukum Pidana. Jakarta: Sekretariat Negara, 1981.
3. Knight B. Simpson's Forensic Medicine (Eleventh Edition). New York: Oxford University, 1997.

4. Gall J, Payne J. Current Practice in Forensic Medicine. Washington: Wiley and Blackwell, 2012.

5. Artz CP, JA Moncrief. The Treatment of Burns (Second Edition). Philadelphia: WB Saunders Company, 1969.

6. Trauma Score - Injury Severity Score: TRISS. [Cited 2013 Aug 17]. Available from:www.trauma.org/archive/scores/tr iss.html

7. Mattox KL, Moore EE, Feliciano DV. Trauma (Seventh Edition). London: McGraw-Hill Professional, 2012. 